FACTA UNIVERSITATIS

Series: Philosophy, Sociology, Psychology and History Vol. 20, № 1, 2021, pp. 13 - 24

https://doi.org/10.22190/FUPSPH2101013P

Original Scientific Paper

\title{
THE FACTORS OF THE LATERAL ORIENTATION OF PORTRAITS
}

\author{
UDC 159.931.072:111.852
}

\author{
Biljana Pejić ${ }^{1}$, Bojana Škorc ${ }^{2}$ \\ ${ }^{1}$ Association of Empirical Studies of the Arts, Belgrade, Serbia \\ ${ }^{2}$ University of Belgrade, Faculty of Fine Arts, Serbia
}

\begin{abstract}
This paper analyses the portraits` aesthetic experience from side perspectives, including left and right orientation. Research was conducted by performing two experiments. The first experiment included 40 participants, the second had 26 participants of both genders who were not trained in the field of fine arts. The stimuli were 12 reproductions of portraits, profile orientation, of models made by famous painters. All the portraits represented adult persons, of different genders (male or female), spatial orientation (left or right) of the model and form (original or inverted). The participants assessed the presented portraits without time limitation on six scales, which measured two dimensions of aesthetic experience: evaluation and activity.

The results support the hypothesis claiming that left side orientation (looking to the left) is valued higher with female portraits, while right side orientation with male portraits is valued higher. It has also been shown that the given differences in estimation were stable, keeping values in the same trend when the portraits were being inverted along a vertical axis.
\end{abstract}

Key words: portrait, orientation, inversion, gender, activity.

\section{INTRODUCTION}

Portraits are very often painted. They appear very often as subjects in art, appearing early in history, and are found in all cultures and civilizations.

Portraits usually have the characteristics of the represented persons, but also the main characteristics of style, historical periods, social and psychological elements present in the current periods, and the artists` style too. All of the abovementioned makes them the main subjects when researching art forms and the psychological characteristics of portrayed characters.

Received July 28, 2020 / Accepted August 30, 2020

Corresponding author: Bojana Škorc

University of Belgrade, Faculty of Fine Arts, Kosančićev venac 29, 11000 Belgrade, Serbia

E-mail: bskorc@yahoo.com

ㄷ 2021 by University of Niš, Serbia | Creative Commons License: CC BY-NC-ND 
Portraits, as the subject of painting, have double meaning: they reflect aesthetic impressions and social moments. Aesthetic and communication levels of expression can be experimentally divided, because based on different physiological fundaments (Gerger, Leder, and Tinio 2011).

It was noticed a while ago that there was tendency for doing portraits using mostly one perspective, one angle, which was confirmed later by various studies. Artists rarely make portraits en face, but instead more often lateral, left or right (Gordon 1974; Grusser, Selke, and Zynda 1988; McManus and Humphrey 1973).

Artists more frequently paint left lateral (Gordon 1974; McManus and Humphrey, 1973). Art students also more often paint left lateral, when they are asked to paint a portrait with lateral orientation (Skorc and Pejic 2012). This tendency is more often presented with female portraits (Conesa, Brunold-Conesa, and Miron 1995; Gordon 1974; Grusser et al. 1988; McManus and Humphrey 1973) and the whole figure (McManus and Humphrey 1973). Rhodes (1985) has a theory that is frequently cited because the left side of the face emphasizes the emotional side more with female characters. With time, this tendency decreased, making it almost not present in contemporary art (Grusser et al. 1988).

Research has shown that the social status of the portrait subject and social distance between the artist and model also affect portrait orientation. According to that, portraits of women from higher social backgrounds, or sovereigns, are more often done from the right lateral perspective (Grusser et al. 1988). On the other hand, some painters, like Rembrandt, more often did right lateral paintings of persons they were close with, or related to (Humphrey and McManus 1973).

Right lateral portraits are assessed as more powerful and more active than those made from the left side (Benjafield and Segalowitz 1993), and are preferred by spectators (McLaughlin and Murphy 1994).

\section{THE RESEARCH OBJECTIVE}

Based on the aforementioned studies, this research aimed to analyze the thesis about the dominant right lateral when perceiving portraits, i.e. the thesis that right lateral portraits are evaluated as stronger, more active and more pleasant. The research objective was to determine:

- whether lateral portraits, which differ by model gender and orientation, are differently estimated in terms of aesthetic dimensions of evaluation and activity; whether there are differences in estimation between various categories of portraits in favour of any individual category;

- the impact of inverted laterals along the vertical axes on the estimation of aesthetic dimensions of evaluation and activity, and whether there are differences in the assessment of inverted lateral portraits compared to the original version.

The following two experiments were performed in order to give answers to the questions above. 


\subsection{Experiment 1}

The experiment was supposed to assess the estimation of portraits which differ by gender of the model and spatial orientation, in terms of evaluation and activity.

\subsubsection{Method}

Participants: The research included 40 participants, of both genders (30 female and 10 male), of an average age of 20 . The participants were not formally trained in the field of fine arts.

Stimuli: Between many available painting prints, those representing the main characteristics of the portraits as artistic expressions well and strongly emphasizing their orientation were chosen. The stimuli were 12 reproductions of color portraits made by famous artists. All the portraits depicted adult persons of different gender (male and female) and space orientation (left and right) of the model. The categories were equated by stimuli number, with 6 female and 6 male portraits, and 6 from each lateral profile ( 3 female and 3 male portraits oriented to the left, 3 female and 3 male portraits oriented to the right). All portraits were from different epochs and artistic styles (see Fig. 1).
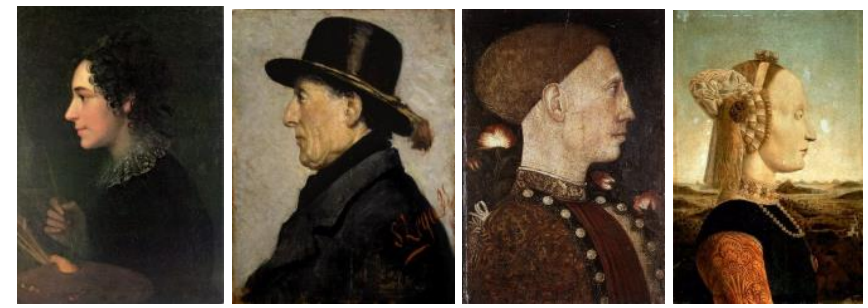

Fig. 1 Example of stimuli - left and right oriented female and male portraits

Instrument: 6 seven-degree scales were given in the form of a semantic differential, used as a part of Instrument for aesthetic assessment (Pejić 2007). The scales measured two dimensions:

- The dimension of evaluation (scales: cold - hot, rough - soft, repulsive - attractive), and

- The dimension of activity (scales: static - dynamic, slow - quick, passive - active).

Procedure: The participants were instructed to focus onto their personal impression, not on the specific characteristics of paintings, while assessing.

Each participant had the task to assess every stimulus on six scales. Their responses were on a scale from -3 to +3 . Value 1 on the scale, positive or negative, always represented a minimal presence, while a value 3 , positive or negative, denoted maximum presence of a characteristic.

The stimuli were displayed via an LCD projector, in random order. The time of exposure and assessment of the stimuli were not restricted. The participants were organized into groups.

Data analysis: The average values were calculated for each dimension. The differences were tested by the Analysis of Variance and t-test for Equality of Means. 


\subsubsection{Results}

Dimension of Evaluation: Results Analysis

The analysis of variance indicated statistically significant effect of gender: $F(1 ; 38)=$ $171,519, p<.001$ and interaction between gender and orientation: $F(1 ; 38)=25,083, p<.001$ on the dimension of evaluation. The basic effect of orientation did not show statistical significance: $F(1 ; 38)=1,625, p>.05$.

Two partial analyses were also carried out, which tested the significant effects of orientation in each group of gender.

The analysis performed on assessments of female portraits, indicated a significant effect of orientation: $F(1 ; 38)=18,404, p<.001$. Left orientation female portraits (left side faces) were valued higher than right orientation female portraits (right side faces) on the dimension of evaluation, (see Fig. 2 and Fig. 3).

The analysis performed on assessments of male portraits indicates a significant effect of orientation: $F(1 ; 38)=7,514, p<.01$. Right orientation male portraits (right side of the faces) were valued higher than left orientation male portraits (left side of the faces) on the dimension of evaluation, (see Fig. 2 and Fig. 3).

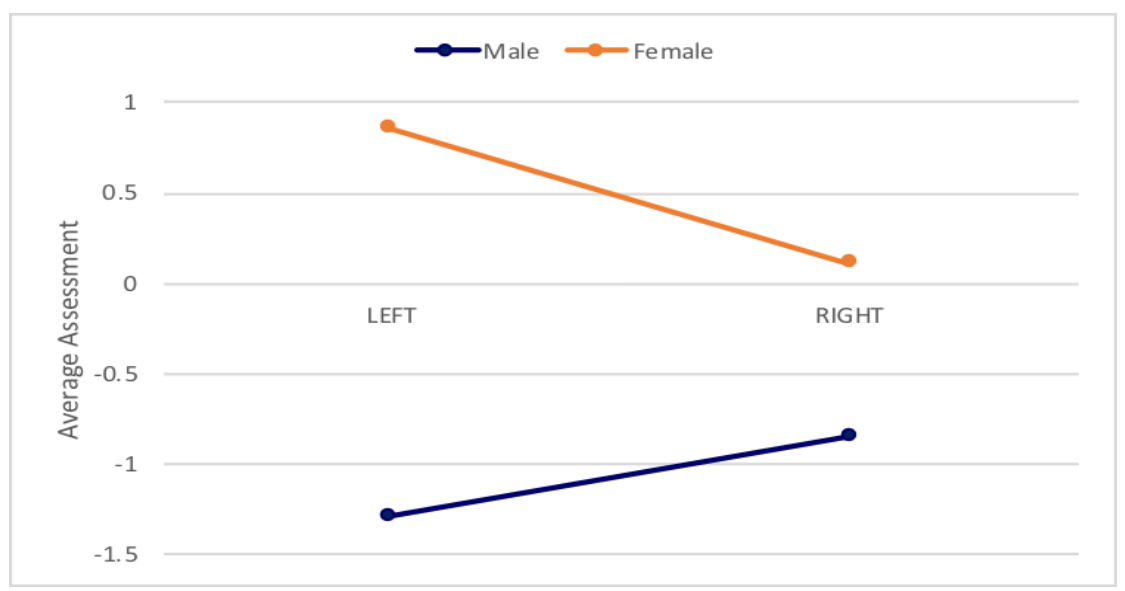

Fig. 2 Assessments of left and right orientation female and male portraits on the dimension of evaluation

Also, two partial analyses were performed, testing the significant effects of gender in each group of orientation.

The analysis done on assessments of left orientation portraits indicates a significant effect of gender: $F(1 ; 38)=167,418, p<.001$. Left orientation female portraits were valued more than left orientation male portraits on the dimension of evaluation (see Fig. 2 and Fig. 3).

The analysis done on assessments of right orientation portraits indicates a significant effect of gender: $F(1 ; 38)=32,035, p<.001$. Right orientation female portraits were valued more than right orientation male portraits on the dimension of evaluation (see Fig. 2 and Fig. 3). 


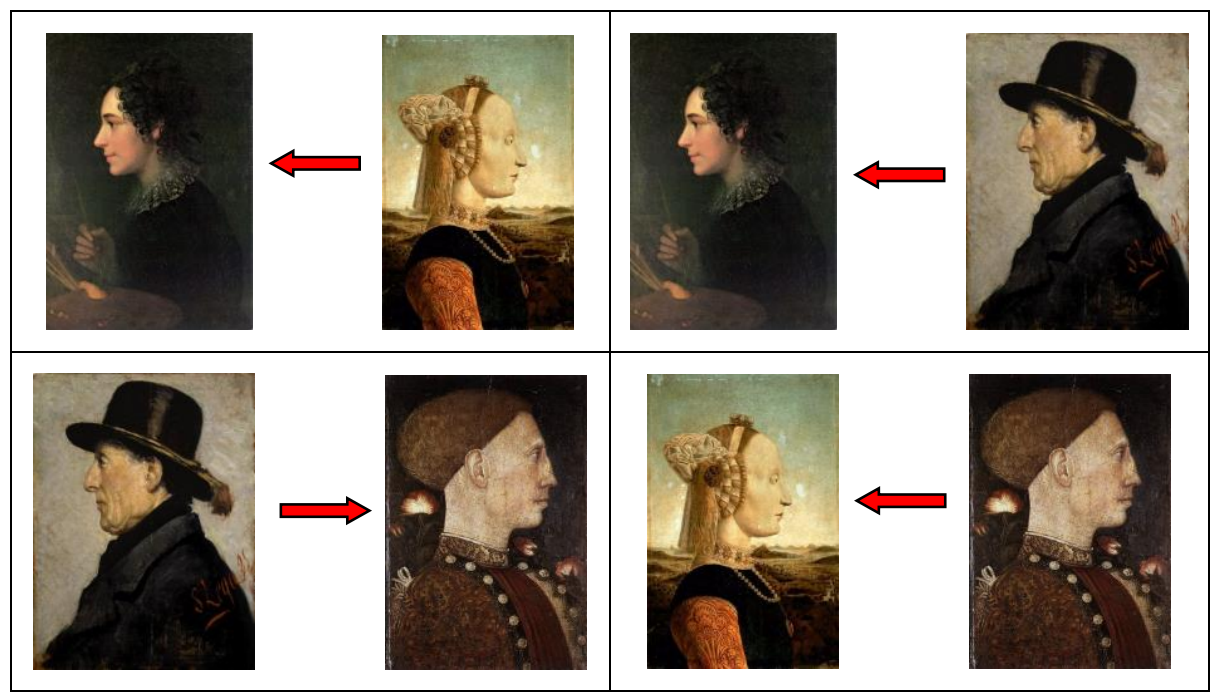

Fig. 3 The choice between left and right orientation female and male portraits on the dimension of evaluation

\section{Dimension of Activity: Results Analysis}

The analysis of variance showed a statistically significant effect of gender: $F(1 ; 38)=$ $13,971, p<.001$ and interaction between gender and orientation: $F(1 ; 38)=3,827, p<.05$ on the dimension of activity. No statistically significant results on orientation were noted: $F(1 ; 38)=0,919, p>.05$.

Two partial analyses were also carried out, testing the significant effects of orientation in each group based on gender.

The analysis done on the assessments of female portraits indicates a significant effect of orientation: $F(1 ; 38)=4,851, p<.05$. Left orientation female portraits were valued more than right orientation female portraits on the dimension of activity (see Fig. 4 and Fig. 5).

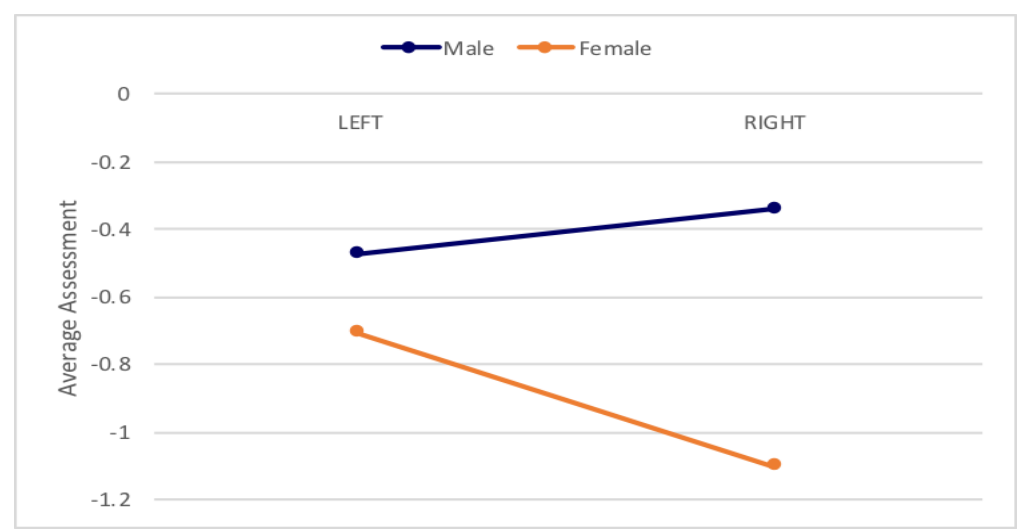

Fig. 4 Assessments of left and right orientation female and male portraits on the dimension of activity 
The analysis done on assessments of male portraits indicates no significant effect of orientation: $F(1 ; 38)=.443, p>.05$. The left and right orientation male portraits have same values on the dimension of activity, (see Fig. 4 and Fig. 5).

Also, two partial analyses were performed, which tested the effect of gender in each group of orientation.

The analysis done on assessments of left orientation portraits indicates no significant effect of gender: $F(1 ; 38)=1,340, p>.05$. The left orientation male and female portraits have same values on the dimension of activity (see Fig. 4 and Fig. 5).

The analysis done on assessments of right orientation portraits indicates a significant effect of gender: $F(1 ; 38)=19,868, p<.001$. The more active are right orientation male portraits than right orientation female portraits (see Fig. 4 and Fig. 5).

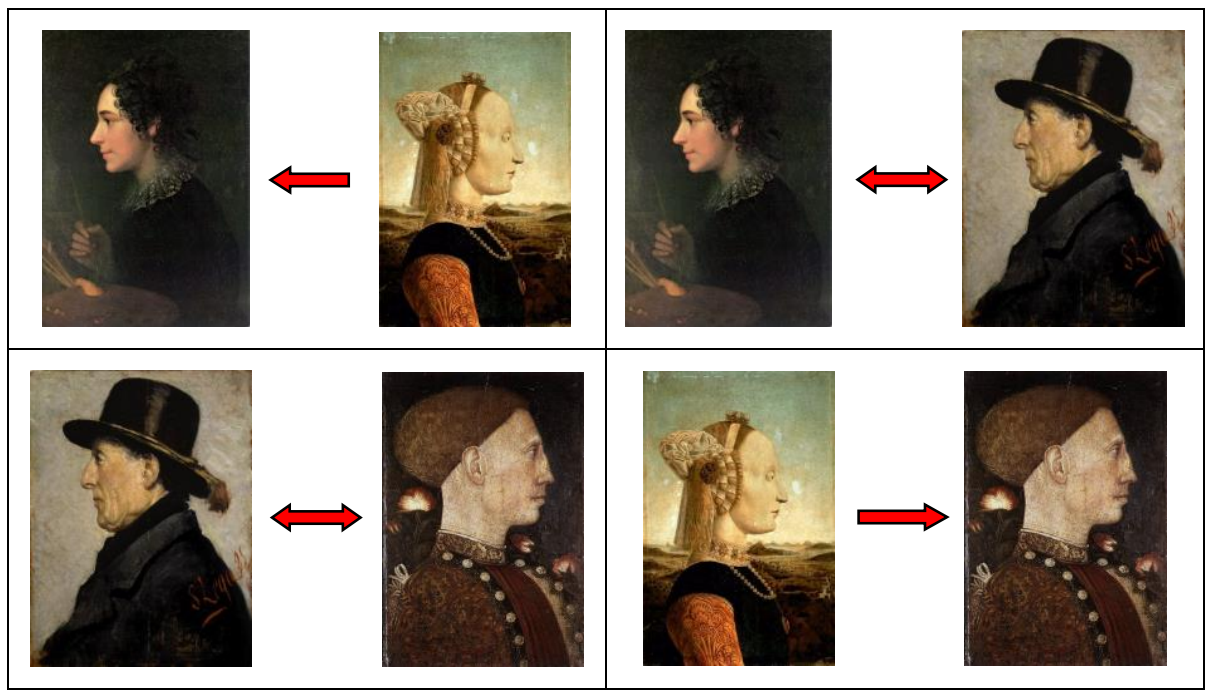

Fig. 5 The choice between left and right orientation female and male portraits on the dimension of activity

\subsection{Experiment 2}

This experiment objective was to test assessments of inverted versions of portraits, which differed based on gender and spatial orientation.

\subsubsection{Method}

Participants: The research included 26 participants, of both genders (17 female and 9 male), with an average age of 20 . The participants were not formally trained in the field of fine arts.

Stimuli: The same stimuli from Experiment 1 were used with inverted versions added. All portraits were inverted along the vertical axis. A total of 24 reproductions of color portraits (12 original and 12 inverted forms).

Instrument: Scales from Experiment 1 were used. 
Procedure: It was the same procedure like in Experiment 1. The only difference was that the participants were given instructions that the portraits will be shown in two versions: original and inverted, but without revealing which version is the original.

Statistical procedure: It was used the same methods as in Experiment 1.

\subsubsection{Results}

The Analysis of variance was calculated for original and inverted forms of portraits which differ based on gender and spatial orientation of the model. Similar results were obtained for original versions on the portraits as in Experiment 1. Regarding that, only results for invert forms will be presented.

\section{Dimension of Evaluation: Results Analysis for inverted stimuli}

The analysis of variance indicated significance only for the interaction between gender and orientation: $F(1 ; 24)=15,358, p<.001$ on the dimension of evaluation for inverted stimuli. No significant results were determined for gender: $F(1 ; 24)=3,226, p>.05$ or just orientation: $F(1 ; 24)=.001, p>.05$.

Since the interaction between the gender of the model and orientation was confirmed, two partial analyses were also performed, testing the significance of orientation in each group based on gender.

The analysis done on assessments of inverted female portraits indicates a significant difference of orientation: $F(1 ; 24)=9,042, p<.01$. Right oriented female portraits (in the original version they were left female portraits) were valued more than left orientation female portraits (in the original version they were right female portraits) on the dimension of evaluation, (see Fig. 6 and Fig. 7).

The analysis done on assessments of inverted male portraits indicates a significant difference between orientations: $F(1 ; 24)=6,649, p<.05$. Left orientation male portraits (in the original version they were right male portraits) were valued more than right orientation male portraits (in the original version they were left male portraits) on the dimension of evaluation, (see Fig. 6 and Fig. 7).

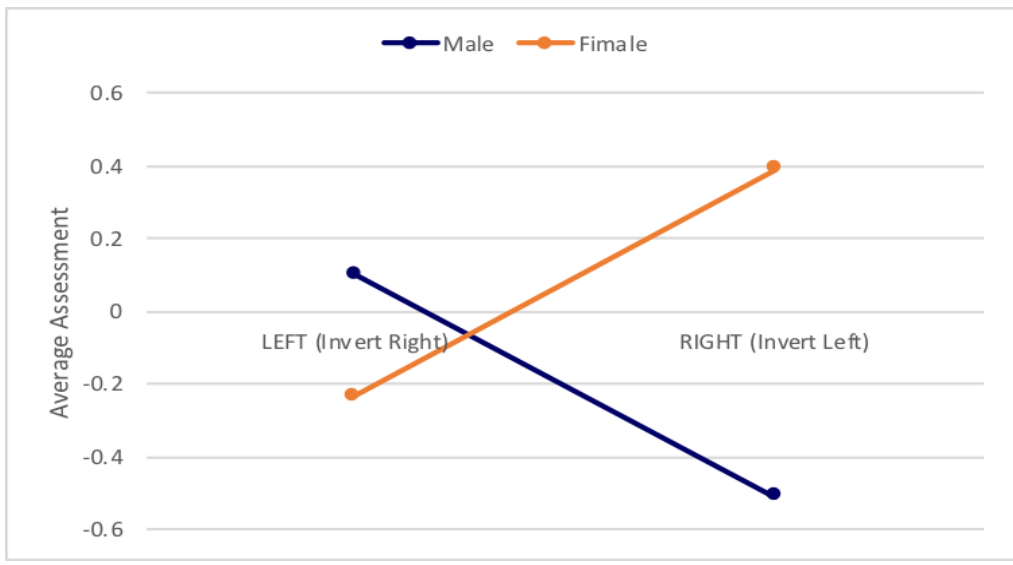

Fig. 6 Assessments of left and right orientation female and male portraits in inverted form on the dimension of evaluation 
Regarding previous findings, two partial analyses were also performed, testing the effects of gender in each group of orientation.

The analysis done on assessments of inverted versions of left orientation portraits indicates no significant effect of gender: $F(1 ; 24)=2,300, p>.05$. The left orientation male and female portraits in the inverted version were valued same on the dimension of evaluation (see Fig. 6 and Fig. 7).

The analysis done on assessments of inverted versions of right orientation portraits indicates a significant effect of gender: $F(1 ; 24)=16,004, p<.001$. Right orientation female portraits in the inverted version were valued more than right orientation male portraits in the inverted version on the dimension of evaluation (see Fig. 6 and Fig. 7).

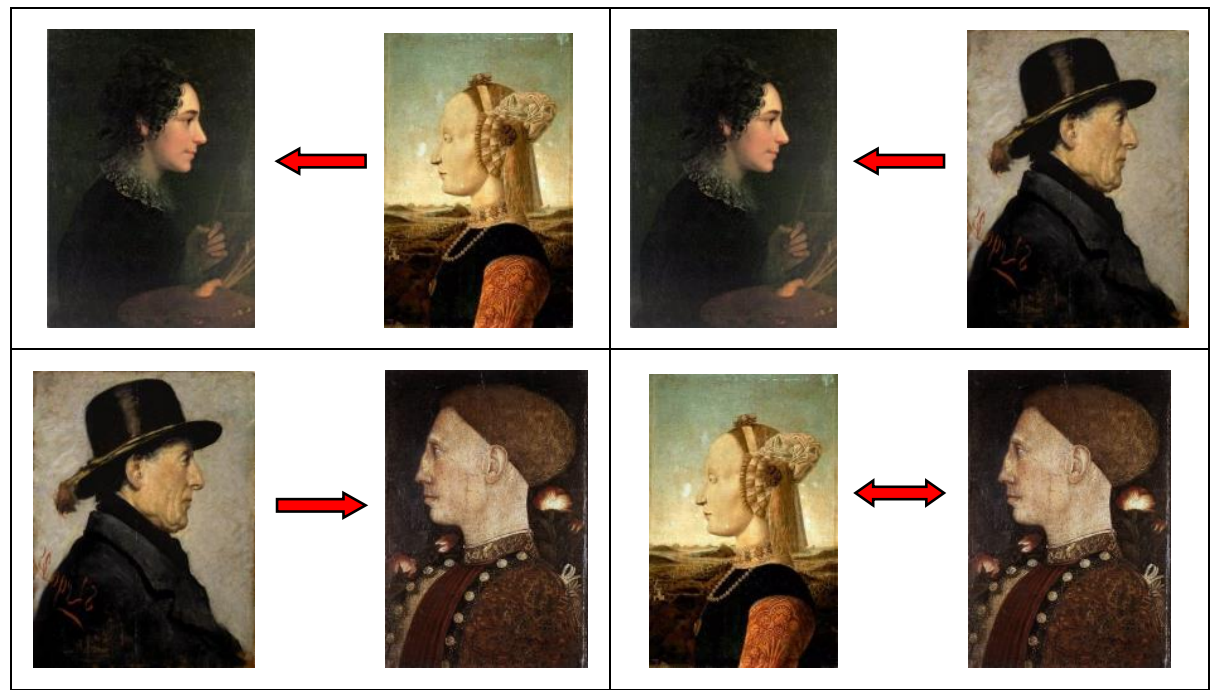

Fig. 7 The choice between left and right orientation female and male portraits in the inverted form on the dimension of evaluation

\section{Dimension of Activity: Results Analysis for inverted stimuli}

The analysis of variance indicated a significant difference only for the interaction between gender and orientation: $F(1 ; 24)=35,891, p<.001$ on the dimension of activity for inverted stimuli. No statistically significant difference for gender effect: $F(1 ; 24)=.820$, $p>.05$ and no significance for orientation effect: $F(1 ; 24)=.003, p>.05$ were determined.

Two partial analyses were performed, testing the effect of orientation in each group based on gender.

The analysis done on assessments of inverted versions of female portraits indicates a significant effect of orientation: $F(1 ; 24)=19,040, p<.001$. The more active are right orientation female portraits (in the original version they were left female portraits) than left orientation female portraits (in the original version they were right female portraits), (see Fig. 8 and Fig. 9).

The analysis done on assessments of inverted versions of male portraits, also, indicates a significant effect of orientation: $F(1 ; 24)=16,939, p<.001$. The more active are left orientation male portraits (in the original they were right male portraits) than right orientation male portraits (in the original version they were left male portraits), (see Fig. 8 and Fig. 9). 


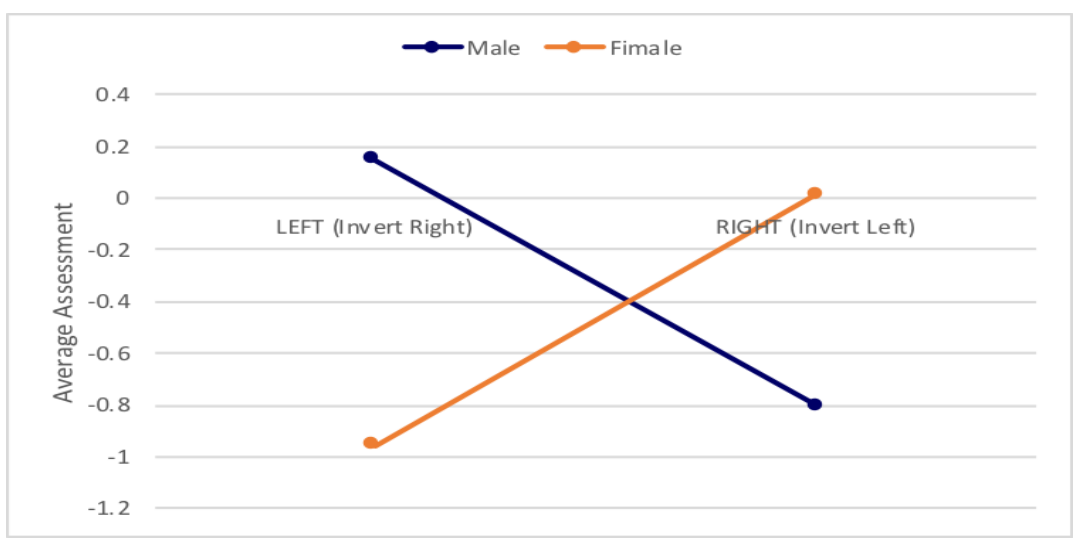

Fig. 8 Assessments of inverted forms of left and right orientation female and male portraits on the dimension of activity

Also, two partial analyses were performed, testing the effect of gender in each group of orientation in the inverted versions.

The analysis done on assessments of the inverted version of left orientation portraits indicates a significant effect of gender: $F(1 ; 24)=23,301, p<.001$. The more active are left orientation male portraits in the inverted version, than left orientation female portraits in the inverted version (see Fig. 8 and Fig. 9).

The analysis done on assessments of inverted versions of right orientation portraits indicates a significant effect of gender: $F(1 ; 24)=13,203, p<.001$. The more active are right orientation female portraits in the inverted version, than right orientation male portraits in the inverted version (see Fig. 8 and Fig. 9).

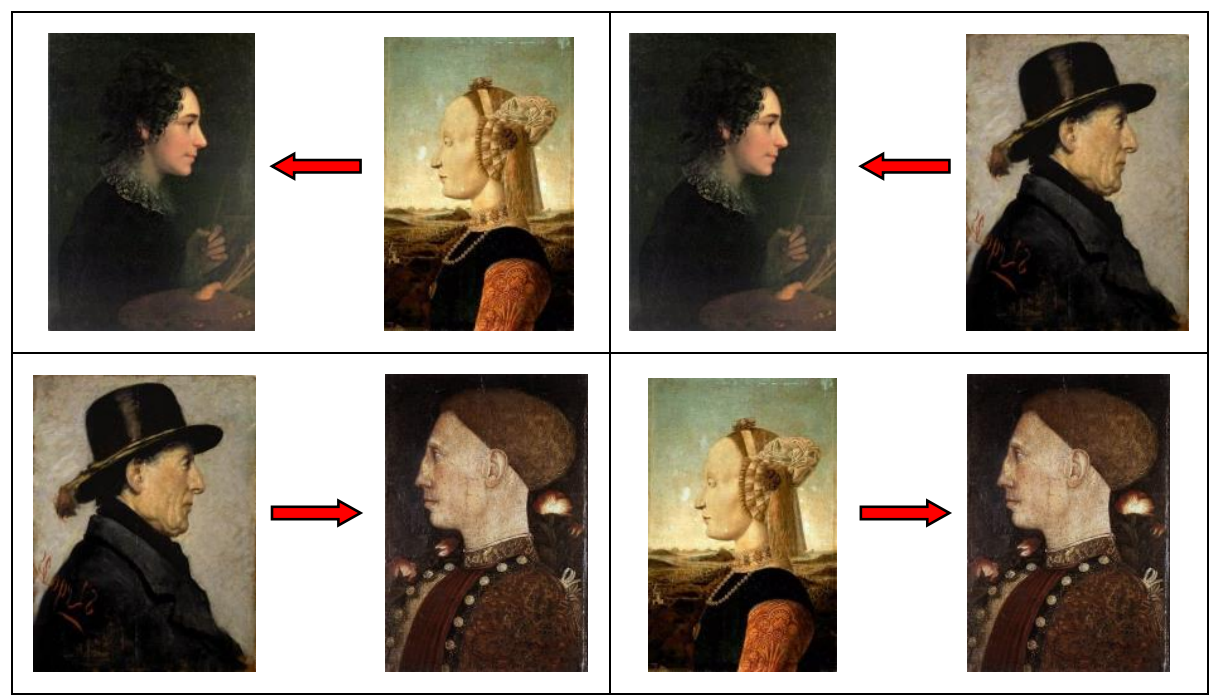

Fig. 9 The choice between invert left and right orientation female and male portraits on the dimension of activity 
While analyzing the results, additional attention should be paid to the fact that the inverted right lateral portrait is actually originally a left lateral portrait and vice versa. According to data from the analysis we can see that the basic trend in assessment remains intact and similar to original form assessments, with the general aesthetic value reduced.

\section{DISCUSSION AND CONCLUSIONS}

Female portraits painted from a lateral perspective, showing left lateral, are perceived as more attractive and active, than right oriented female portraits. On the other hand, right oriented male portraits are perceived as more attractive and active than left oriented male portraits. Given results support findings about stronger dominance of left orientation on paintings representing females, and right orientation on paintings representing males.

Findings partly verify the thesis about an existing absolute dominance, i.e. aesthetic assessment of right oriented portraits, which is related to male models, while left orientation is dominant with female models.

The results also show that impressions of portraits, observed through dimensions of evaluation and activity, are not related just to formal characteristics such as orientation and model gender, but also to the artist's general idea and composition of the painting. Regarding that, we found statistically significant differences on tested dimensions in the original and inverted versions.

Assessments of original versions by value evaluation - dimension of expression related to evaluative aesthetic judgment and dimension of pleasantness indicate differences favoring female portraits, no matter how oriented they are. Left oriented portraits are considered the most gentle, warmest and most attractive, while right oriented are perceived less consistently with those categories. On the other hand, male portraits are perceived as cold, rough and repellent.

Inverted versions assessed by the dimension of evaluation show a tendency to favour specific categories of male and female portraits. Contrary to original versions, right oriented inverted female portraits are seen as gentle, warm and attractive (left oriented in the original version), while left oriented inverted female portraits (right oriented in the original version) are seen as rough, cold and unattractive.

Left oriented male inverted portraits (right oriented in the original version) are seen the same as right oriented inverted female portraits with less intensity, while right oriented inverted male portraits (left oriented in the original version) are seen more in a negative way, like left oriented inverted female portraits.

Assessments of original versions by dimension of activity indicate that all categories of portraits are given below average values, but differences are found in the direction toward the artistic image of male portraits in both versions. Right oriented male profiles were seen as less static, slow and passive, and right oriented female portraits were seen as most static, slow and passive. The results indicate that activity as a dimension is more sustained with right oriented male portraits.

Assessments of the inverted version based on activity have higher values for left oriented inverted male portraits. Those (right oriented in the original version) are assessed as dynamic, fast and active. Right oriented inverted female portraits are assessed in a similar way (left oriented in the original version), although with less intensity. Right oriented inverted male portraits (left oriented in the original version) and left oriented inverted female portraits (right oriented in the original) are valued with a negative prefix by this dimension. They are seen as slow, static and passive, especially for female portraits, those who are left oriented inverted. 
This topic opens an interesting question about what is happening on the impression level when untypical original portraits are inverted into something that is expected to be a typical form. This transformation in the mirror obviously does not give linear effects, but completely the opposite - the impression is polarized toward the negative. The findings are telling us that the original artist's idea is not a coincidence, an atypical portrait orientation in the original version is aesthetically valued more than the inverted one.

The results can easily be related to many empirical results and interpretations.

According to some authors, there are differences in hemispheres regarding expression of emotion (Rhodes, 1985), the right hemisphere produces emotions which are manifested more on the left side of the face. Since artists are more sensitive by intuition, they showed women as emotional and more often portrayed by left side.

Other authors included an agent, model activator (Chatterjee 2002). According to this idea, the subject models are in a passive role, so artists show them more often from the left side. The cultural aspect (the traditionally submissive role of women) leads to women rarely being seen as "agents" unlike men, which is why they are painted more often from the left side. Men are presented from the right side in order to deliver a message about the "agent" more clearly, pointing to them as more active subjects.

Favoring female portraits on the evaluation dimension, especially those painted from the left side, is confirmed by the fact that artists showed female portraits more often as left oriented. Some authors created a habit and tendency for this orientation with their regular audience (McManus and Humphrey 1973). This is more likely to be explained by laws of perception processing visual forms in light of theory emphasizing the "pregnanz" quality of object - an optimal form of organization, since it is constantly present in many different studies.

Favouring male portraits, especially made from the right side, on the dimension of activity, confirms the thesis about the aesthetic dominance of right oriented portraits (Benjafield and Segalowitz 1993).

On the other hand, assessments of inverted versions of portraits indicating these two categories, left oriented female and right oriented male portraits, are less intact in way of balance, when inverted. Speaking of aesthetics, they are more stable. Even inverted, their balance and composition are not seen as distorted. Sometimes, in some cases, they are more valued than originals, as evidenced in assessments of activity.

The results on inverted forms are compatible with the thesis that male right-oriented profiles are more dominant, because the right side of the face is seen as more active whether shown in the original or inverted version.

At the same time, the sample structure makes us feel more careful, because it is uneducated artistic audience, without special interest in visual art. There is a strong influence of previous education in art on receiving art (Funch 1997; Pejić 2004; Pejić and Škorc 2009; Škorc 2012). It is also important to consider the modern explosion of visual communication within mass media, connected with a decreasing formal education for art, all affecting moving focus from a complex impression toward fast and superficial perception of "beauty" according to the attraction of the model, in this case this would be the human face. That is how "beauty" is separated from artistic production and values of cultural products, becoming fast ad hoc assessments of whether to meet the actual person or to put the painting on our wall. Superficial aesthetic judgment is based on the model`s characteristics, and cannot be separated from pragmatic thinking. Still, the results are not minimized because they are related to a typical assessor. The results given from a standard audience are related to the relevant public share (most of the general population), but without the certain conclusion that we are speaking 
about an audience that is relevant for making judgments on art, being capable of developing and analyzing its impression. As shown in Adorno`s work, a passive audience could not be audience at all - it is necessary to question different subgroups and systematically develop deeper communication layers between the audience and language of art (Škorc 2012).

\section{REFERENCES}

Benjafield, John, and Sidney Segalowitz. "Left and right in Leonardo's drawings of faces". Empirical Studies of the Arts 11 (1993): 25-32.

Chatterjee, Anjan. "Portrait profiles and the notion of agency". Empirical Studies of the Arts 20, 1 (2002): 33-41.

Conesa, Jorge, Cynthia Brunold-Conesa, and M. Miron. "Incidence of the half-left profile pose in single subject portraits". Perceptual and Motor Skills 81 (1995): 920-922.

Funch, Bjarne Sode. The Psychology of Art Appreciation. Copenhagen: Museum Tusculanum Press, University of Copenhagen, 1997.

Gerger, Gernot, Helmut Leder, and Pablo Tinio. "Faces versus patterns: Exploring aesthetic reactions using facial EMG". Psychology of Aesthetic, Creativity and the Arts 5, 3 (2011): 241-250.

Gordon, Ian. "Left and right in Goya's portraits". Nature 249 (1974): 197-198.

Grüsser, Otto-Joachim, Thomas Selke, and Barbara Zynda. "Cerebral lateralization and some implications for art, aesthetic perception and artistic creativity". In Beauty and the brain. Biological aspects of aesthetics, edited by Ingo Rentschler, Barbara Herzberger, and David Epstein, 257-293. Boston: Birkhauser, 1988.

Humphrey, Nicholas, and McManus, Chris. "Status and the left cheek". New Scientist 59 (1973): 437-439.

McLaughlin, John, and Kimberly Murphy. "Preference for profile orientation in portraits". Empirical Studies of the Arts 12 (1994): 1-7.

McManus, Ian, and Humphrey, Nicholas. "Turning the left cheek". Nature 243 (1973): 271-272.

Pejić, Biljana. Tipovi crteža u likovnoj umetnosti $i$ modusi estetske preferencije (magistarski rad). Univerzitet u Beogradu, Filozofski fakultet, 2004.

Pejić, Biljana. "Skala procene estetskog doživljaja". Rad predstavljen na XIII Naučnom skupu: Empirijska istraživanja u psihologiji na Filozofskom fakultetu, Univerziteta u Beogradu, Februar, 07-08, 2007. Knjiga Rezimea, 23-24.

Pejić Biljana i Bojana Škorc. "Uticaj sistematskog likovnog obrazovanja na estetsko suđenje". Banjalučki novembarski susreti: Naučna i duhovna utemeljenost društvenih reformi. Knjiga 10, 333-343. Banjaluka: Filozofski fakultet, 2009.

Rhodes, Gillian. "Perceptual asymmetries in face recognition". Brain and Cognition 4 (1985): 197-218.

Skorc, Bojana and Biljana Pejic. "Orientation of Canonic Representation". Review of Aesthetics, Media and Culture: $22^{\text {nd }}$ Biennal Congress of The International Association of Empirical Aesthetics. Taipei, Taiwan. August 22-25, 2012, Book, 351-357. http://www2.ntnu.edu.tw

Škorc, Bojana. Kreativnost u interakciji: psihologija stvaralaštva. Beograd: Mostart, 2012.

\section{FAKTORI LATERALNE ORIJENTACIJE PORTRETA}

U radu se ispituju komponente estetskog doživljaja portreta rađenih iz profila. Istraživanje je organizovano kroz dva eksperimenta. U prvom eksperimentu je učestvovalo 40, a u drugom 26 ispitanika oba pola, koji nisu posebno obučavani iz oblasti likovnih umetnosti. Stimulusni materijal se sastojao od dvanaest reprodukcija portreta lica iz profila poznatih likovnih umetnika. Portreti su predstavljali odrasle osobe. Razlikovali su se po modelu (ženski/muški); orijentaciji modela u prostoru (levo/desno) $i$ formi portreta (originalni/invertovani). Ispitanici su bez vremenskog ograničenja procenjivali stimuluse na 6 skala, koje su merile dve dimenzije estetskog doživljaja: evaluaciju i aktivitet. Rezultati idu u prilog hipotezi o višem estetskom vrednovanju leve orijentacije (gleda na levo) kod ženskih portreta, odnosno desne orijentacije kod muških portreta. Takođe je pokazano da ova razlika u procenama između polova opada ali se zadržava u istom trendu kada se isti portreti invertuju po vertikalnoj osi.

Ključne reči: portret, pol, inverzija, evaluacija, aktivitet. 